\title{
Lipocalin: A Novel Diagnostic Marker for Hepatocellular Carcinoma in Chronic Liver Disease Patients in Egypt
}

\author{
Hoda Aly Abd El Moety ${ }^{1}$, Rania Mahamed El Sharkawy ${ }^{1}$, Nevin Abd El Menem Hussein ${ }^{2}$ \\ ${ }^{1}$ Chemical Pathology, Medical Research Institute, Alexandria University, Alexandria, Egypt; ${ }^{2}$ Applied Chemistry, Medical Research \\ Institute, Alexandria University, Alexandria, Egypt. \\ Email: hodaabdelmoety@yahoo.com
}

Received July $13^{\text {th }}, 2013$; revised August $15^{\text {th }}, 2013$; accepted September $10^{\text {th }}, 2013$

Copyright (C) 2013 Hoda Aly Abd El Moety et al. This is an open access article distributed under the Creative Commons Attribution License, which permits unrestricted use, distribution, and reproduction in any medium, provided the original work is properly cited.

\begin{abstract}
Hepatocellular carcinoma is one of the most prevalent life-threatening human cancers with etiological factors chronic viral hepatitis $\mathrm{B}$ and $\mathrm{C}$ infections. Tumor cell dispersion relies on the loss of homotypic cell-cell adhesion. Invasion through basement membrane and interstitial extracellular matrix is another key event for metastatic progression, which requires the action of a series of proteolytic enzymes named matrix metalloproteinases, secreted by tumor cells that enhance tumor invasiveness and metastasis. TIMPs are dominant inhibitors of MMPs and able to control MMP-mediated ECM breakdown by binding active forms of MMPs. Lipocalin-2 is known as neutrophil gelatinase associated lipocalin promotematrix degradation and tumor progression. Aim: To evaluate the importance of lipocalin for diagnosis HCC in Egyptian chronic liver disease patients. Subjects and Methods: 50 patients and 25 controls. (G-1) 25 HCC on top of hepatitis C. (G-2) 25 hepatitis C. The following done: schistosoma antibodies, ASAM, LKM-1, ANA AKA and CBC. Hepatitis B surface antigen, Hepatitis C antibodies AFP, Cupper and zinc, Matrix metaloprotinase-9, TIMP-1 and Neutrophil gelatinase-associated lipocalin. Results: Median value of MMP-9 level in G-I (206 $\mu \mathrm{g} / \mathrm{L})$ is significantly higher than G-2 $(100 \mu \mathrm{g} / \mathrm{L})$ and G $3(49 \mu \mathrm{g} / \mathrm{L}) \mathrm{p}<0.001$. TIMP-9 median value G-1 $(48 \mu \mathrm{g} / \mathrm{L})$ is significantly lower than G-2 $(54 \mu \mathrm{g} / \mathrm{L})$ and G-3 $(113 \mu \mathrm{g} / \mathrm{L}) \mathrm{p}<0.001$. Lipocalin-2 median levels are significantly higher in G-I $(389 \mathrm{ng} / \mathrm{mL})$ than G-2 $(166$ $\mathrm{ng} / \mathrm{ml})$ versus $\mathrm{G}-3(60 \mathrm{ng} / \mathrm{mL}) \mathrm{p}<0.001$. Lipocalin-2 associated with increasing lobular inflammation, ballooning \& fibrosis with MMP-9 has an important role in pathogenesis of liver cirrhosis and HCC. Conclusion: We elucidated predictive value for MMPs, TIMPs, and progression metastasis of hepatocellular carcinoma. Liver cell impairment alters metabolism of trace metals as zinc and copper, with possible relationship of these changes to pathogenesis of chronic liver disease. Lipocalin-2 can be used as a future diagnostic marker with better sensitivity and specificity than MMP-9 for the progression of hepatocelluar carcinoma.
\end{abstract}

Keywords: Lipocalin-2; MMP-9; TIMP-1; Cu; Zn; HCC

\section{Introduction}

Hepatocellular carcinoma (HCC) is one of the most prevalent life-threatening human cancers that is not only increasing in worldwide incidence in the past decade [14], but also a leading cause of cancer-related deaths worldwide [3-6]. HCC is an aggressive and enigmatic disease, which represents approximately $85 \%$ of liver cancers $[5,6]$. The most prominent etiological factors associated with HCC consist of chronic viral hepatitis $\mathrm{B}$ and $\mathrm{C}$ infections [4,7-9], nonalcoholic fatty liver disease [10-12], and toxin and alcohol exposure [6,9]. The development and progression of HCC is a multistep and long-term process characterized by the progressive sequential evolution of morphologically distinct preneoplastic lesions (formed as a result of chronic liver injury, necro-inflammation and regeneration, small cell dysplasia, lowgrade and high grade dysplastic nodules) that culminates in the formation of HCC $[5,13]$.

Dispersion of tumor cells from the primary tumor is considered one of the key events for metastatic progression. Tumor cell dispersion relies on the loss of homotypic cell-cell adhesion, which is largely mediated by Ecadherin/catenin complex [14]. Invasion through basement membrane and interstitial extracellular matrix is another key event for metastatic progression, which requires the action of a series of proteolytic enzymes named matrix metalloproteinases (MMPs) [15,17]. MMPs are a group of zinc-dependent endopeptidases that share 
many structural and functional properties but with different substrate specificities $[15,18,19]$.

The ability of cancer cells to degrade the extracellular matrix and basement membrane is an important initial step in the process of tumor invasion [20,22]. Matrix metalloproteinases (MMPs), secreted by tumor cells, are extracellular matrix-degrading enzymes that enhance tumor invasiveness and metastasis [23,24]. MMP-9 plays a key role in the invasive ability and the degradation of the basement membrane, which is composed of type IV collagen [21].

The activity of MMPs is regulated by a group of molecules named tissue inhibitors of MMP (TIMPs) that reside in the normal tissue and counter react with MMPs with a $1: 1$ stoichiometry $[15,19,25,26]$. There are four members of the TIMP family designated TIMP-1, -2, -3 and -4 [27]. Tissue inhibitors of matrix metalloproteinase (TIMPs) are the dominant inhibitors of MMPs and are able to control MMP-mediated ECM breakdown by binding active or latent forms of MMPs in a 1:1 molecular ratio [28].

The expression of MMPs is regulated by various factors, such as growth factors, cytokines, and proteinases inhibitors. The endogenous tissue inhibitors of metalloproteinses (TIMPs) are specific inhibitors of MMPs. Im- balance between the MMPs and TIMPs might, therefore, contribute to degradation or deposition of the ECM [29,30]. Inhibition of MMP-mediated migration of invasion could thus provide a means of preventing cancer metastasis [31].

Hepatic fibrosis is the common end point to chronic injury of variable aetiology. Also it is a bidirectional process with significant reversible component. HSC is the principal cell producing extracellular matrix during fibrogenesis and the main source of TIMP-1 which inhibits the endogenous matrix-degrading activity of the MMPs, thus promoting scar deposition.

Hepatic macrophages are the master regulator of this dynamic fibrogenesis-fibrosis resolution paradigm, where they are rich sources of scar degrading MMPs as MMP-9 which can promote HSC apoptosis which is critical feature of scar resolution. Loss of the pro-inflammatory profibrotic signals expressed by microphages during fibrogenesis might alter local milieu to favour fibrosis resolution [31] (Figures 1 and 2) [32,33].

Lipocalin-2 (LCN2), also known as NGAL (neutrophil gelatinase-associated lipocalin), is a $25-\mathrm{KDa}$ transporter belonging to the lipocalin super family. LCN2 binds MMP-9 and forms a 115-135-KDa MMP-9-LCN2 complex, preventing the degradation of MMP-9. The

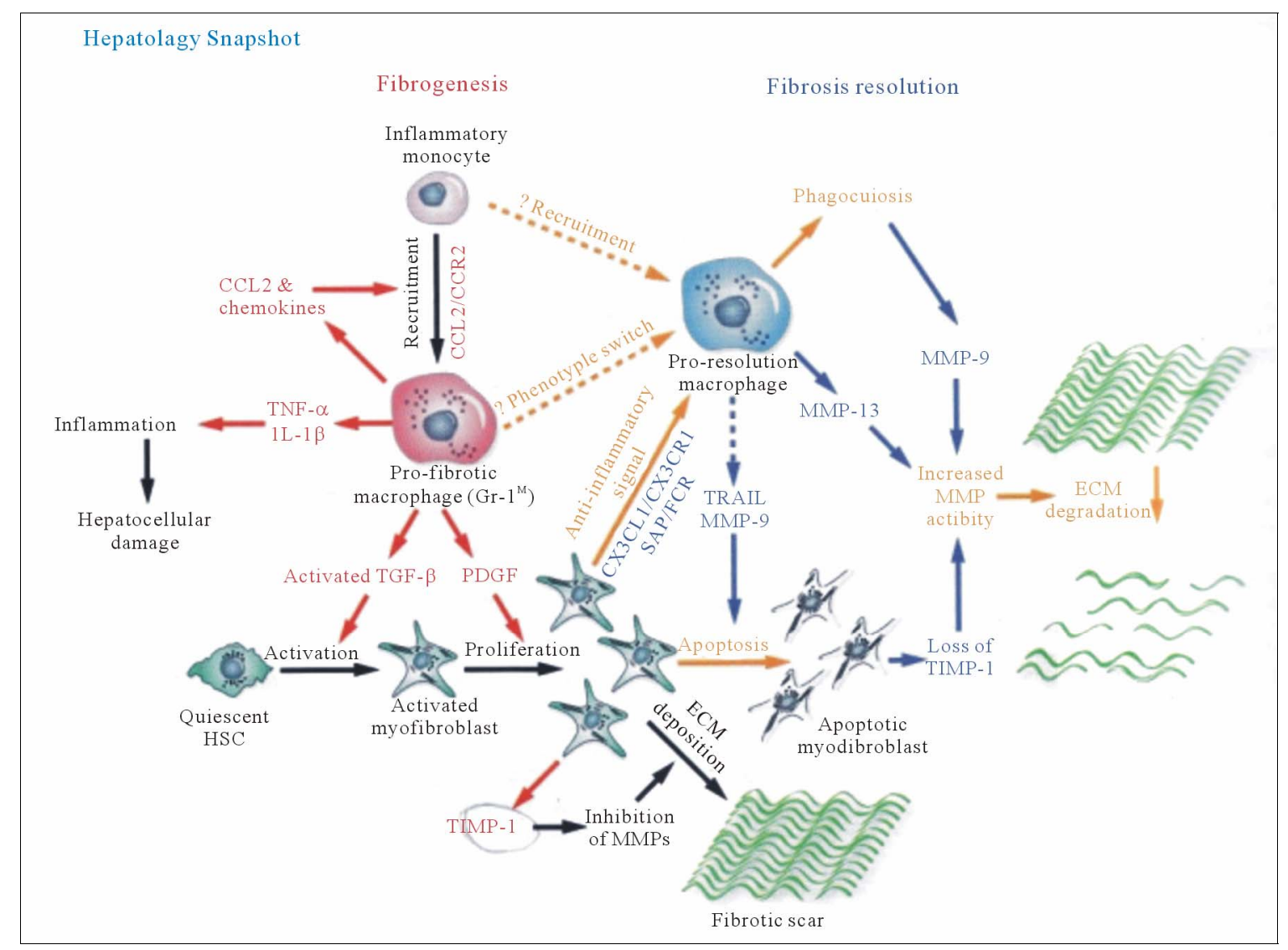

Figure 1. Macrophages: Central regulators of hepatic fibrogenesis and fibrosis resolution [32]. 


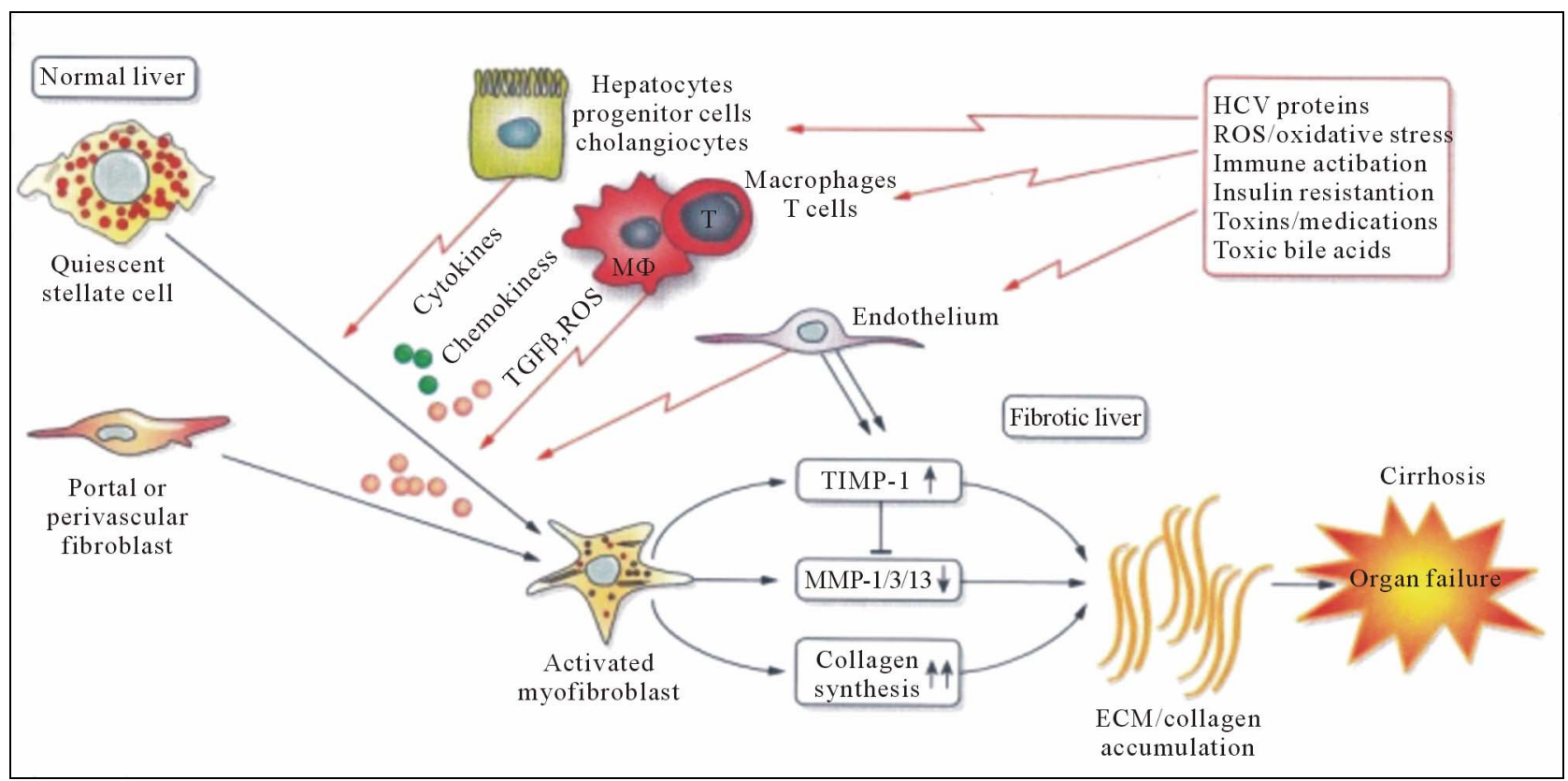

Figure 2. Factors that promote fibrosis progression to cirrhosis [33].

MMP-9/LCN-complex is present in the urine of breast cancer patient and is believed to promote MMP-mediated matrix degradation and tumor progression [32-36].

\section{Aim}

The aim was to evaluate the importance of lipocalin for diagnosis of hepatocllular carcinoma in Egyptian chronic liver disease patients.

\section{Subjects and Methods}

The present study was carried out on 75 adult subjects their age ranged from 40 to 60 years. The hepatic patients group (50 subjects) selected from those admitted from the hepatology and oncology Departments, Medical Research Institute, University of Alexandria from 2010 to 2012 and 25 healthy volunteers were considered as a control group (with matched age).

The patients were classified into the following groups:

1) Group-1: 25 hepatocellular carcinoma on top of hepatitis $\mathrm{C}$ group.

2) Group-2: 25 hepatitis $C$ group.

3) Group-3: 25 healthy subjects as control group.

All subjects lived in the same rural area (the Abbess group of villages on the edge of the Alexandria governorate) and were seen at the Internal Medicine and oncology Departments of Alexandria University's Medical Research Institute Teaching Hospital, in Alexandria, Egypt. The study protocol was approved by Alexandria University's Ethical Committee and all the subjects gave their written informed consent before participating in the study.
All subjects were subjected to the following parameters were done: schistosoma antibodies using indirect haemagglutination test [37]. Antismooth muscle antibodies ASAM, liver kidney microsomal antibodies LKM-1, antinuclear antibodies ANA and anti-keratin antibodies AKA by indirect immunoflourescent technique [38]. Complete blood picture on automated cell counter and verified by smear examination [39]. Hepatitis B surface antigen [40], Hepatitis C antibodies [41], Serum alpha fetoprotein by ELISA [41]. Cupper and zinc by atomic absorption spectrophotometry [42]. Matrix metaloprotinase-9 and Inhibitor (TIMP-1) and Neutrophil gelatinase-associated lipocalin (NGAL) by ELISA [43-45].

Blood sampling: $5 \mathrm{ml}$ of venous blood were withdrawn from all patients and control subjects. All blood samples were collected into sterile tubes (gel separation tube and EDTA for CBC), gel separation tubes were left to be clotted then centrifuged at $25^{\circ} \mathrm{C}$ for 10 minutes; serum was stored at $-80^{\circ} \mathrm{C}$ until used for determination of serum MMP9, TIMP-1 and NGAL. All other parameters were analyzed immediately with no storage.

\section{Results}

The present study showed a statistically significant difference $(p<0.001)$ between the studied groups for TIMP-1, MMP-9, Lipocaline-2, $\mathrm{Cu}, \mathrm{Zn}$ and $\mathrm{Cu} / \mathrm{Zn}$ ratio (Table 1).

A significant negative correlation between the MMP-9 and TIMP in the HCC \& HCV group $(r=-0.0483, p=$ $0.015)$ while no significant correlations in the other groups for all other parameters (Table 2). 
Lipocalin: A Novel Diagnostic Marker for Hepatocellular Carcinoma in Chronic Liver Disease Patients in Egypt

Table 1. Comparison between the different studied groups according to different parameters.

\begin{tabular}{|c|c|c|c|c|}
\hline & $\mathrm{HCC} \& \operatorname{HCV}(\mathrm{G} 1)$ & $\mathrm{HCV}(\mathrm{G} 2)$ & Control(G3) & $\mathrm{p}$ \\
\hline \multicolumn{5}{|l|}{$T I M P-1$} \\
\hline Mean \pm SD & $47.44 \pm 8.98$ & $58.04 \pm 9.52$ & $110.80 \pm 9.36$ & ( $\cap 0^{*}$ \\
\hline Median & 48.0 & 54.0 & 113.0 & \\
\hline $\mathrm{p}_{1}$ & $<0.001^{*}$ & $<0.001^{*}$ & & \\
\hline $\mathrm{p}_{2}$ & \multicolumn{2}{|c|}{$0.001^{*}$} & & \\
\hline Mean $\pm \mathrm{SD}$ & $204.64 \pm 36.23$ & $99.80 \pm 9.80$ & $49.88 \pm 3.09$ & $<0001^{*}$ \\
\hline Median & 206.0 & 100.0 & 49.0 & \\
\hline $\mathrm{p}_{1}$ & $<0.001^{*}$ & $<0.001^{*}$ & & \\
\hline $\mathrm{p}_{2}$ & \multicolumn{2}{|c|}{$<0.001^{*}$} & & \\
\hline \multicolumn{5}{|l|}{ LIPOCALIN-2 } \\
\hline Median & 389.0 & 166.0 & 60.0 & \\
\hline $\mathrm{p}_{1}$ & $<0.001^{*}$ & $<0.001^{*}$ & & \\
\hline $\mathrm{p}_{2}$ & \multicolumn{2}{|c|}{$<0.001^{*}$} & & \\
\hline \multicolumn{5}{|l|}{$\mathrm{Cu}$} \\
\hline Mean \pm SD & $1.05 \pm 0.23$ & $0.92 \pm 0.23$ & $0.46 \pm 0.09$ & $<0001^{*}$ \\
\hline Median & 1.10 & 1.0 & 0.50 & -0.001 \\
\hline $\mathrm{p}_{1}$ & $<0.001^{*}$ & $<0.001^{*}$ & & \\
\hline $\mathrm{p}_{2}$ & \multicolumn{2}{|c|}{0.053} & & \\
\hline \multicolumn{5}{|l|}{$Z n$} \\
\hline Mean \pm SD & $0.30 \pm 0.05$ & $0.56 \pm 0.06$ & $0.67 \pm 0.04$ & $<0001^{*}$ \\
\hline Median & 0.31 & 0.56 & 0.67 & \\
\hline $\mathrm{p}_{1}$ & $<0.001^{*}$ & $<0.001^{*}$ & & \\
\hline \multicolumn{5}{|l|}{$\mathrm{Cu} / \mathrm{Zn}$ ratio } \\
\hline Mean \pm SD & $3.24 \pm 1.17$ & $1.90 \pm 0.46$ & $0.68 \pm 0.14$ & $<0.001^{*}$ \\
\hline Median & 3.13 & 2.04 & 0.67 & \\
\hline $\mathrm{p}_{1}$ & $<0.001^{*}$ & $<0.001^{*}$ & & \\
\hline $\mathrm{p}_{2}$ & \multicolumn{2}{|c|}{$<0.001^{*}$} & & \\
\hline
\end{tabular}

*: Statistically significant at $\mathrm{p} \leq 0.05$ between the three studied groups; $\mathrm{p}$ : $\mathrm{p}$ value for $\mathrm{F}$ test (ANOVA) for comparing between the different studied group; $\mathrm{p}_{1}$ : $\mathrm{p}$ value for Post Hoc test (Scheffe) for comparing between control with each group; $\mathrm{p}_{2}$ : p value for Post Hoc test (Scheffe) for comparing between HCC \& HCV and $\mathrm{HCV}$.

Table 2. Correlation between different parameters in each studied groups.

\begin{tabular}{|c|c|c|c|c|c|c|c|c|c|}
\hline & & \multicolumn{2}{|c|}{ MMP-9 } & \multicolumn{2}{|c|}{ LIPOCALIN-2 } & \multicolumn{2}{|c|}{$\mathbf{C u}$} & \multicolumn{2}{|c|}{ Zn } \\
\hline & & $\mathbf{r}$ & $\mathbf{p}$ & $\mathbf{r}$ & $\mathbf{p}$ & $\mathbf{r}$ & $\mathbf{p}$ & $\mathbf{r}$ & $\mathbf{p}$ \\
\hline \multirow{5}{*}{ HCC \& HCV } & TIMP & $-0.483^{*}$ & 0.015 & -0.210 & 0.314 & -0.035 & 0.868 & 0.225 & 0.281 \\
\hline & MMP-9 & & & 0.040 & 0.849 & 0.174 & 0.405 & -0.087 & 0.680 \\
\hline & Lipocalin-2 & & & & & 0.086 & 0.681 & -0.114 & 0.587 \\
\hline & $\mathrm{Cu}$ & & & & & & & -0.134 & 0.523 \\
\hline & TIMP & -0.056 & 0.791 & -0.052 & 0.806 & -0.298 & 0.148 & 0.100 & 0.636 \\
\hline \multirow{3}{*}{ HCV } & MMP-9 & & & 0.002 & 0.991 & 0.097 & 0.643 & -0.349 & 0.088 \\
\hline & Lipocalin-2 & & & & & 0.230 & 0.269 & -0.121 & 0.563 \\
\hline & $\mathrm{Cu}$ & & & & & & & -0.313 & 0.128 \\
\hline \multirow{4}{*}{ Control } & TIMP & -0.086 & 0.683 & -0.165 & 0.429 & 0.148 & 0.481 & -0.193 & 0.357 \\
\hline & MMP-9 & & & 0.299 & 0.147 & -0.202 & 0.333 & $0.513^{*}$ & 0.009 \\
\hline & Lipocalin-2 & & & & & -0.296 & 0.151 & 0.302 & 0.143 \\
\hline & $\mathrm{Cu}$ & & & & & & & -0.047 & 0.823 \\
\hline
\end{tabular}

r: Pearson coefficient; *: Statistically significant at $\mathrm{p} \leq 0.05$. 
Positive significant correlation is present between GGT and lipocaline-2 in the HCC \& HCV group ( $r=$ 0.465 ) and between AFP and TIMP in the HCV group ( $\mathrm{r}$ $\left.=0.505^{*}\right)$ and between $\mathrm{Zn}$ and MMP-9 in the control group, while negative significant correlation between TIMP and GGT in the control group $\left(\mathrm{r}=-0.485^{*}\right)$ (Table
3).

No significant difference is present between the studied groups as regards the AFP $(p=0.051)$ (Table 4).

The sensitivity, specificity, PPV, NPV and accuracy is calculated for NGAL, MMP-9, TIMP and AFP (Table 5).

Table 3. Correlation between TIMP-1, MMP-9 and LIPOCALIN-2 with different parameters in each group.

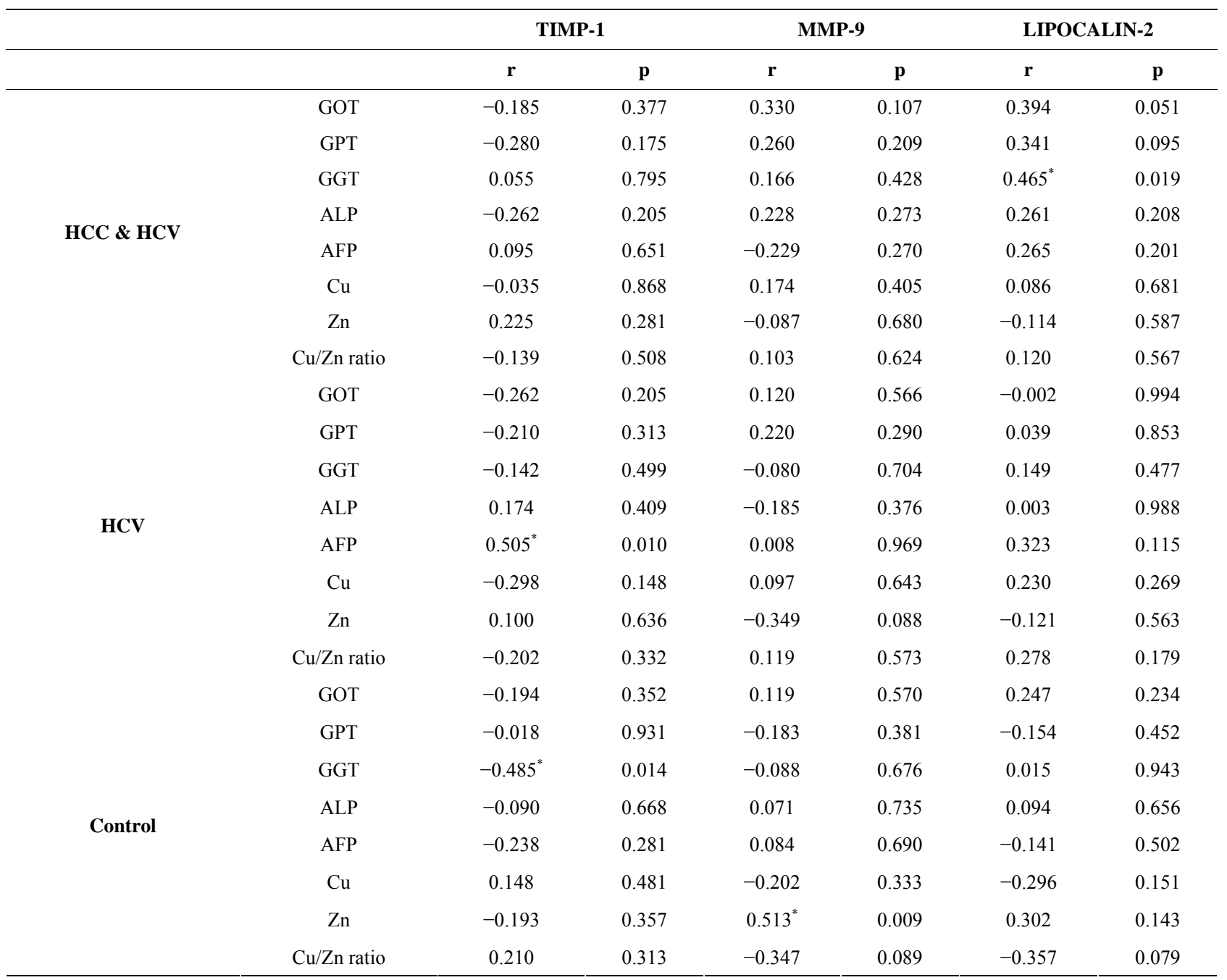

r: Pearson coefficient; *: Statistically significant at $\mathrm{p} \leq 0.05$.

Table 4. Comparison between the different studied groups according to AFP.

\begin{tabular}{|c|c|c|c|c|}
\hline & HCC \& HCV & HCV & Control & $\mathbf{p}$ \\
\hline$A F P$ & & & & \multirow{5}{*}{0.051} \\
\hline Mean \pm SD & $1014.87 \pm 2817.24$ & $46.54 \pm 50.85$ & $1.77 \pm 1.55$ & \\
\hline Median & 250.0 & 15.0 & 1.20 & \\
\hline $\mathrm{p}_{1}$ & 0.117 & 0.096 & & \\
\hline $\mathrm{p}_{2}$ & \multicolumn{2}{|c|}{0.995} & & \\
\hline
\end{tabular}

*: Statistically significant at $\mathrm{p} \leq 0.05$ between the three studied groups; $\mathrm{p}$ : $\mathrm{p}$ value for Kruskal Wallis test for comparing between the different studied group; $\mathrm{p} 1$ : $\mathrm{p}$ value for Mann Whitney test for comparing between control with each group; p2: p value for Mann Whitney test) for comparing between HCC \& HCV and $\mathrm{HCV}$. 
Table 5. Agreement (sensitivity, specificity and accuracy) for NGAL, MMP-9, Inhibitor and AFP with HCV and HCC \& HCV.

\begin{tabular}{|c|c|c|c|c|c|c|c|c|}
\hline & & $\mathrm{HCV}$ & $\mathrm{HCC} \& \mathrm{HCV}$ & Sensitivity & Specificity & PPV & NPV & Accuracy \\
\hline \multirow[b]{2}{*}{ NGAL } & $\leq 200$ & 25 & 0 & \multirow[b]{2}{*}{100.0} & \multirow[b]{2}{*}{100.0} & \multirow[b]{2}{*}{100.0} & \multirow[b]{2}{*}{100.0} & \multirow[b]{2}{*}{100.0} \\
\hline & $>200$ & 0 & 50 & & & & & \\
\hline \multirow{2}{*}{ MMP-9 } & $\leq 117$ & 21 & 5 & \multirow{2}{*}{80.0} & \multirow{2}{*}{84.0} & \multirow{2}{*}{83.33} & \multirow[b]{2}{*}{80.77} & \multirow[b]{2}{*}{82.0} \\
\hline & $>117$ & 4 & 20 & & & & & \\
\hline \multirow[b]{2}{*}{ Inhibitor } & $>48$ & 23 & 12 & \multirow[b]{2}{*}{52.0} & \multirow[b]{2}{*}{92.0} & \multirow[b]{2}{*}{86.67} & \multirow[b]{2}{*}{65.71} & \multirow[b]{2}{*}{72.0} \\
\hline & $\leq 48$ & 2 & 13 & & & & & \\
\hline AFP & $>103$ & 22 & 1 & 96.0 & 88.0 & 88.89 & 95.65 & 92.0 \\
\hline
\end{tabular}

\section{Discussion}

Liver cancer is the fifth common diagnosed cancer worldwide and the third leading cause of cancer death. Hepatocellular carcinoma primarily develops in cirrhosis resulting from chronic infection by hepatitis $\mathrm{B}$ and $\mathrm{C}$ viruses, alcoholic injury and to a lesser extent from genetically determined disorders such as heamochromatosis [46].

This associations is alarming due to globally high prevalence of this conditions and may contribute to the rising incidence of $\mathrm{HCC}$ which is increasingly commonly in the united states with an age adjusted incidence rising from 1.5 to 4.9 per 100,000 Individuals in the past 30 years. This worrisome trend has been primarily attributed to the high prevalence of chronic hepatitis $\mathrm{C}$ in this population, so there is an urgent need to develop and validate noninvasive tests that can accurately reflect the full spectrum of hepatic inflammation and fibrosis in chronic hepatitis $\mathrm{C}$ patients [47-49].

Liver fibrosis is traditionally viewed as a progressive pathological process involving multiple cellular and molecular events that lead ultimately to deposition of excess matrix proteins in the extracellular space. When this process is combined with ineffective regeneration and repair, there is increasing distortion of the normal liver architecture, and the end result is cirrhosis. The role of hepatic stellate cells (HSCs) in this process has led to important validity of this "progression-only" model [50].

Current evidence indicates that liver fibrosis is dynamic and can be bidirectional involving phases of progression and regression, that in addition to increased matrix synthesis, this pathological process involves major changes in the regulation of matrix degradation [51].

In the extracellular space, matrix degradation occurs predominantly as a consequence of the action of a family of enzymes called the matrix metalloproteinases (MMPs). These are secreted from HSC cells into the extra-cellular space as proenzymes, which are then activated by a number of specific, usually cell surface-associated, cleav- age mechanisms.

The active enzymes are in turn inhibited by a family of tissue inhibitors of metalloproteinases (TIMP-1 to -4). By this combination of mechanisms, extracellular matrix degradation is closely regulated, which prevents inadvertent tissue damage. The three most relevant MMPs are gelatinase A (MMP-2), gelatinase B (MMP-9), and stromelysin (MMP-3).

Progelatinase B (MMP-9) is found in liver, but the principal cellular source is the Kupffer cell. Progelatinase B expression is significantly increased with Kupffer cell activation, but the majority is secreted in the proenzyme form. Progelatinase B can be activated by plasmin and stromelysin $[52,53]$.

HSC-mediated activation of progelatinase A and B is significantly induced in the presence of collagen type I (the principal matrix protein found in fibrotic liver).This could contribute to further degradation of the normal liver matrix, leading to Increased activation of HSCs and increased synthesis of type I collagen, this positive feedback loop would theoretically promote progression of liver fibrosis [52-54].

A non-invasive means of assessment of disease activity and stage would be very helpful, particularly in monitoring patients with chronic hepatitis $\mathrm{C}$ virus (HCV) infection overtime. An ideal test would be simple, readily reliable, inexpensive, accurate, and sensitive.

In the present study it is evident that median value of the MMP-9 level in G-I was $(206 \mu \mathrm{g} / \mathrm{L}))$ which was significantly higher than G-2 $(100 \mu \mathrm{g} / \mathrm{L})$ and G $3(49 \mu \mathrm{g} / \mathrm{L})$ where $\mathrm{p}<0.001$. Also TIMP-9 median value in G-1 (48 $\mu \mathrm{g} / \mathrm{L})$ was significantly lower than G-2 $(54 \mu \mathrm{g} / \mathrm{L})$ and G-3 $(113 \mu \mathrm{g} / \mathrm{L})$ where $\mathrm{p}<0.001$ (Table 1).

G-1 showed negative significant correlation between MMP-9 and TIMP- I were $(r=-0.483 p=0.015)$, but G2 and G-3 only showed negative correlation were $(\mathrm{r}=$ $-0.056 \mathrm{p}=0.791)$ and $(\mathrm{r}=-0.086 \mathrm{p}=0.683)$ respectively (Table 2).

MMP-9 in: G1 was positively correlated with GOT, 
GPT, GGT, ALP and $\mathrm{Cu}(\mathrm{r}=0.330 / \mathrm{p}=0.107, \mathrm{r}=260 / \mathrm{p}$ $=0.209, \mathrm{r}=0.166 / \mathrm{p}=0.428, \mathrm{r}=0.228 / \mathrm{p}=0.273, \mathrm{r}=$ $0.174 / \mathrm{p}=0.405$ ), while it was negatively correlated with AFP and $\mathrm{Zn}(\mathrm{r}=-0.224 / \mathrm{p}=0.270, \mathrm{r}=-0.087 / \mathrm{p}=0.680)$ respectively (Table 3 ).

G-2 was positively correlated with GOT, GPT, AFP, $\mathrm{Cu}(\mathrm{r}=0.120 \mathrm{p}=0.566, \mathrm{r}=0.290 \mathrm{p}=0.039, \mathrm{r}=0.008 \mathrm{p}$ $=0.969, \mathrm{r}=0.097 \mathrm{p}=0.643)$. While it showed negative correlation with GGT, ALP, Zn $(r=-0.080 \mathrm{p}=0.704, \mathrm{r}$ $=-0.185 \mathrm{p}=0.376, \mathrm{r}=-349 \mathrm{p}=0.088)$ respectively (Table 3).

TIMP-1 in group G-1 was inversely correlated with GOT, GPT, ALP and $\mathrm{Cu}(\mathrm{r}=-0.185 \mathrm{p}=0.377, \mathrm{r}=$ $-0.280 \mathrm{p}=0.175, \mathrm{r}=-262 \mathrm{p}=0.205, \mathrm{r}=-0.325 \mathrm{p}=$ $0.868)$ respectively. While it showed positive correlation with GGT, AFP and $\mathrm{Zn}(\mathrm{r}=0.055 \mathrm{p}=0.795, \mathrm{r}=0.095 \mathrm{p}$ $=0.651, r=0.225 \mathrm{p}=0.281$ ) respectively (Table 3).

While it showed negative correlation with GOT, GPT, GGT and $\mathrm{Cu}(\mathrm{r}=-0.262 \mathrm{p}=0.205, \mathrm{r}=-210 \mathrm{p}=0.313, \mathrm{r}$ $=0.142 \mathrm{p}=0.499, \mathrm{r}=-0.298 \mathrm{p}=0.148)$ and positive correlation with ALP, $\mathrm{Zn}(\mathrm{r}=0.174 \mathrm{p}=0.409, \mathrm{r}=0.100$ $\mathrm{p}=0.636)$ and a positive significant correlation with AFP $(r=0.505 p=0.010)$ respectively in G-2 (Table 3).

These results were in accordance with Ralf $\mathrm{L}$ et al. [55] who stated that several biochemical indicators have been discussed as a potential non-invasive serum markers of fibro-proliferation. Among them the matrix metalloproteinase (MMPs) and their tissue inhibitors (TIMPs) have been shown to correlate with the development of hepatitis $\mathrm{C}$ induced cirrhosis, as a result of an imbalance between enhanced matrix synthesis and diminished breakdown of connective tissue proteins, the net result of which is increased deposition of extracellular matrix. Decreased activity of ECM-removing MMPs is mainly due to an over expression of their specific inhibitors (TIMPs) [56].

Sheng Zhang et al. [57] stated that the expressive balance between matrix metalloproteinase-9 (MMP-9) and its tissue inhibitor of metalloproteinase-1 (TIMP-1) plays a critical role in maintaining the degradation and synthesis of extracellular matrix. Loss of such balance is associated with invasion and metastasis of tumors and predict poor prognosis.

Zu-huaGao et al. [58] also stated that well-differentiated hepatocellular carcinoma and to less differentiated tumors was associated with a gradual decrease in tissue inhibitors of metalloproteinase, but higher levels of MMPs. These data suggest that tissue expression of MMPs and their inhibitors could be useful markers to predict the progression and metastasis of hepatocellular carcinoma.

The lipocalins (NEGAL) constitute a broad but evolutionarily conserved family of small proteins, which share a high similarity in their tertiary structures in spite of a low degree in amino-acid sequence identity: three highly conserved sequence motifs form a funnel-like $\beta$ barrel which encloses a hydrophobic pocket for the internal ligand binding.

Individual lipocalins have been implicated in diverse physiological roles ranging from odor recognition by binding proteins like retinol-binding protein, purpurin, $\alpha$-1-microglobulin, $\beta$-lactoglobulin to the regulation of cell homeostasis and functions as carrier apolipoprotein D which transports sterols and steroid hormones $[59,60]$.

Harald $\mathrm{T}$ et al. [61] also stated that human neutrophil lipocalin (HNL), a member of the large family of lipocalins that exhibit various physiological functions, is coexpressed in granulocytes with progelatinase B (MMP9). Part of it is covalently bound to the proenzyme and therefore may play a possible role in the activation process of promatrix metalloproteinases and can exert an enzyme-activating effect in the regulation of inflammatory and pathophysiological responses of MMP-9 activation.

Our present study was in accordance with the above documented results where Lipocalin-2 median levels were significantly higher in G-I $(389 \mathrm{ng} / \mathrm{mL})$ than G-2 $(166 \mathrm{ng} / \mathrm{ml})$ Versus G-3 $(60 \mathrm{ng} / \mathrm{mL})$ where $\mathrm{p}<0.001$ (Table 1).

Lipocalin -2 (Negal) also in the present study showed positive correlations with MMP-9 in G-1, G-2 \& G-3 where $(r=0.040 \mathrm{p}=0.849, \mathrm{r}=0.002 \mathrm{p}=0.991, \mathrm{r}=0.299$ $\mathrm{p}=0.147$ respectively). But lipocalin-2 showed negative correlations with TIMP-1 in G-1, G-2 and G-3 were $(\mathrm{r}=$ $-0.210 \mathrm{p}=0.314, \mathrm{r}=-0.052 \mathrm{p}=0.804, \mathrm{r}=-0.165 \mathrm{p}=$ 0.429 ) respectively (Table 2 ).

Lipocalin-2 (NEGAL) in G-1 it showed positive significant correlation with GGT $\left(r=0.465^{*} \mathrm{p}=0.019\right)$, it was positively correlated GOT, GPT, ALP, AFP, $\mathrm{Cu}(\mathrm{r}=$ $0.394 \mathrm{p}=0.051, \mathrm{r}=0.341 \mathrm{p}=0.095, \mathrm{r}=0.261 \mathrm{p}=0.208$, $\mathrm{r}=0.265 \mathrm{p}=0.201, \mathrm{r}=0.086 \mathrm{p}=0.681$ ) respectively. While it was negatively correlated with $\mathrm{Zn}(\mathrm{r}=-0.114 \mathrm{p}$ $=0.587$ ).

In G-2 it showed negative correlation with GOT and $\mathrm{Zn}(\mathrm{r}=-0.002 \mathrm{p}=0.994, \mathrm{r}=-0.121 \mathrm{p}=0.563)$, while it was positively correlated with GPT, GGT, ALP, AFP, $\mathrm{Cu}(\mathrm{r}=0.039 \mathrm{p}=0.853, \mathrm{r}=0.149 \mathrm{p}=0.477, \mathrm{r}=0.003 \mathrm{p}$ $=0.988, r=0.323 \mathrm{p}=0.115, \mathrm{r}=0.230 \mathrm{p}=0.269)$ respectively (Table 3).

Lipocalin-2 was associated with increasing lobular inflammation, ballooning \& fibrosis together with matrix metalloproteinase (MMP-9) has an important role in the pathogenesis of liver cirrhosis (LC) and hepatocellular carcinoma (HCC) [62].

Suzuki K et al. [63] stated that biochemical and nutriational roles of trace elements is widely recognized, since metals are found as constituent components of many metalloproteins and metalloenzymes. Some trace elements such as copper act as cofactors particularly in the 
biosynthesis of collagen. As the disease progress from chronic hepatitis to liver cirrhosis, serum zinc concentrations decrease, while the copper concentration increases. In the patients with hepatocellular carcinoma, serum concentrations of trace elements are similar to those of liver cirrhosis. In the patients with acute hepatitis, serum zinc concentrations decrease, while copper concentrations decrease. These trace element abnormalities may reflect such pathological conditions as liver dysfunction, cholestasis, hepatic fibrosis or liver regeneration. Also Copper accumulation in fibrotic livers caused by chronic hepatitis $\mathrm{C}$ may contribute to hepatic injury [64].

We observed significant changes in the trace element serum levels of patients having hepatocellular carcinoma, relative to those of healthy controls $(\mathrm{p}<0.001)$, where $\mathrm{Cu}$ median value in $\mathrm{G}-1(1.10 \mu \mathrm{g} / \mathrm{L})$ was significantly higher than G-2 $(1 \mu \mathrm{g} / \mathrm{L})$ than $\mathrm{G} 3(0.5 \mu \mathrm{g} / \mathrm{L})$. In contrast, $\mathrm{Zn}$ median value in G-I $(0.31 \mu \mathrm{g} / \mathrm{L})$ was significantly lower than G-2 $(0.56 \mu \mathrm{g} / \mathrm{L})$ than G-3 $(0.67 \mu \mathrm{g} / \mathrm{L})$ where $\mathrm{p}$ $<0.001$ (Table 1).

Also there was negative significant correlation between $\mathrm{Cu}$ and $\mathrm{Zn}$ in the three different groups where G-I $(\mathrm{r}=-0.134 \mathrm{p}=0.523), \mathrm{G}-2(\mathrm{r}=-0.313 \mathrm{p}=0.128)$ and G-3 $(r=-0.047 \mathrm{p}=0.823)$. (Table 2)

Moreover, we found significantly elevated median value of $\mathrm{Cu}$ : $\mathrm{Zn}$ ratios in G-1 (3.13) patients having hepatocellular carcinoma than G-2 (2.04) than G-3 (0.67) where $(\mathrm{p}<0.001)$.

$\mathrm{Cu} / \mathrm{Zn}$ ratios were also positively correlated with MMP-9 in G-1 and G-2 ( $r=0.103 \mathrm{p}=0.624, \mathrm{r}=0.119 \mathrm{p}$ $=0.573)$ also with NEGAL in G-1 and G-2 $(\mathrm{r}=0.120 \mathrm{p}=$ $0.567, \mathrm{r}=0.278 \mathrm{p}=0.179$ ) respectively. (Table 3 )

Our findings imply that the levels of some trace elements, such copper, zinc and $\mathrm{Cu}$ : $\mathrm{Zn}$ ratios, might serve as biomarkers for the increased severity of viral hepatic damage.

These results suggested that changes in liver cell pathology compounded by functional impairment may alter the metabolism of trace metals, in particular, zinc and copper, with possible relationship of these changes to the pathogenesis of chronic liver disease [65-68]

The present study revealed that the AUROC for lipocalin-2 at a cut-off $>200 \mathrm{ng} / \mathrm{ml}$ was 1.000 , where $\mathrm{p}<$ 0.0001 , while for MMP-9 at a cut-0ff $>117 \mu \mathrm{g} / \mathrm{L}$ was 0.962 , where $\mathrm{p}=0.023$ and for TIMP-1 at a cut off $>48$ $\mu \mathrm{g} / \mathrm{L}$ was 0.771 , where $\mathrm{p}=0.001$ (Figure 3 ).

Also the diagnostic performance for lipocalin-2 in G-1 was $100 \%$ while MMP-9 in the same group showed a sensitivity of $80 \%$ with PPV of $83.33 \%$ and specificity of $84 \%$ with NPV of $80.77 \%$ with an accuracy of $82 \%$. Whereas the diagnostic performance for TIMP-1 in G-1 showed sensitivity $52 \%$ with PPV $86.67 \%$ and specificity of $92 \%$ with NPV $65.71 \%$ with an accuracy of $72 \%$.

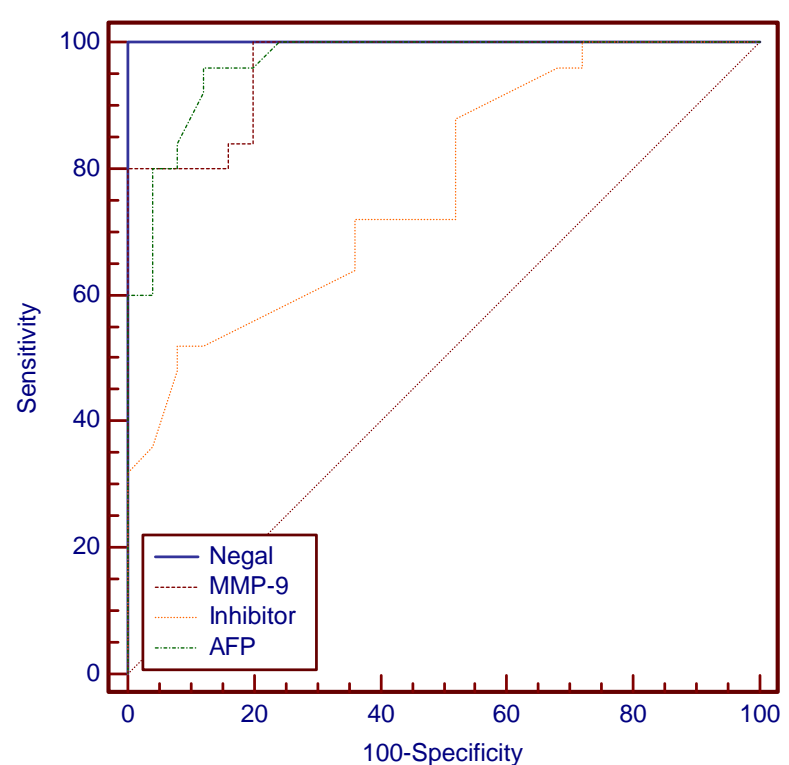

Figure 3. ROC curve for AFP, NGAL, MMP-9 and Inhibitor with HCV and HCC \& HCV.

\section{Conclusions}

We elucidated the predictive value for evaluation of MMPs, TIMPs, and the progression metastasis of hepatocellular carcinoma.

Liver cell pathology compounded by functional impairment alters the metabolism of trace metals as zinc and copper, with a possible relationship of these changes to the pathogenesis of chronic liver disease.

Lipocalin-2 can be used as a future diagnostic marker with better sensitivity and specificity than MMP-9 for the progression of hepatocelluar carcinoma.

\section{REFERENCES}

[1] M. M. Center and A. Jemal, "International Trends in Liver Cancer Incidence Rates," Cancer Epidemiology, Biomarkers \& Prevention, Vol. 20, No. 11, 2011, pp. $2362-$ 2368. http://dx.doi.org/10.1158/1055-9965.EPI-11-0643

[2] E. P. Simard, E. M. Ward, R. Siegel and A. Jemal, "Cancers with Increasing Incidence Trends in the United States 1999 through 2008," CA: A Cancer Journal for Clinicians, 2012, in press.

[3] S. S. Thorgeirsson and J. W. Grisham, "Molecular Pathogenesis of Human Hepatocellular Carcinoma," Nature Genetics, Vol. 31, No. 4, 2002, pp. 339-346. http://dx.doi.org/10.1038/ng0802-339

[4] P. A. Farazi and R. A. de Pinho, "Hepatocellular Carcinoma Pathogenesis: From Genes to Environment," $\mathrm{Na}$ ture Reviews Cancer, Vol. 6, No. 9, 2006, pp. 674-687. http://dx.doi.org/10.1038/nrc1934

[5] A. P. Venook, C. Papandreou, J. Furuse and L. L. de Guevara, "The Incidence and Epidemiology of Hepatocellular 
Carcinoma: A Global and Regional Perspective," Oncologist, Vol. 15, No. 4, 2010, pp. 5-13.

http://dx.doi.org/10.1634/theoncologist.2010-S4-05

[6] J. D. Yang and L. R. Roberts, "Epidemiology and Management of Hepatocellular Carcinoma," Infectious Disease Clinics of North America, Vol. 24, No. 4, 2010, pp. 899- 919. http://dx.doi.org/10.1016/j.idc.2010.07.004

[7] D. Kremsdorf, P. Soussan, P. Paterlini-Brechot and C. Brechot, "Hepatitis B Virus Related Hepatocellular Carcinoma: Paradigms for Viral-Related Human Carcinogenesis," Oncogene, Vol. 25, No. 27, 2006, pp. 3823-3833. http://dx.doi.org/10.1038/sj.onc.1209559

[8] M. Levrero, "Viral Hepatitis and Liver Cancer: The Case of Hepatitis C," Oncogene, Vol. 25, 2006, pp. 3834-3847. http://dx.doi.org/10.1038/sj.onc.1209562

[9] J. A. Sanyal, S. K. Yoon and R. Lencioni, "The Etiology of Hepatocellular Carcinoma and Consequences for Treatment," Oncologist, Vol. 15, No. 4, 2010, pp. 14-22. http://dx.doi.org/10.1634/theoncologist.2010-S4-14

[10] A. B. Siegel and A. X. Zhu, "Metabolic Syndrome and Hepatocellular Carcinoma," Cancer, Vol. 115, No. 24, 2009, pp. 5651-5661. http://dx.doi.org/10.1002/cncr.24687

[11] T. M. Welzel, B. I. Graubard, S. Zeuzem, H. B. El-Serag, J. A. Davila and K. A. McGlynn, "Metabolic Syndrome Increases Risk of Primary Liver Cancer in the United States: A Study in the SEER-Medicare Database," Hepatology, Vol. 54, No. 2, 2011, pp. 463-471.

http://dx.doi.org/10.1002/hep.24397

[12] E. Hashimoto and K. Tokushige, "Hepatocellular Carcinoma in Non-Alcoholic Steatohepatitis: Growing Evidence of an Epidemic," Hepatology Research, Vol. 42, No. 1, 2012, pp. 1-14. http://dx.doi.org/10.1111/j.1872-034X.2011.00872.x

[13] L. Libbrecht, V. Desmet and T. Roskams, "Preneoplastic Lesions in Human Hepatocarcinogenesis," Liver International, Vol. 25, No. 1, 2005, pp. 16-27. http://dx.doi.org/10.1111/j.1478-3231.2005.01016.x

[14] B. P. L. Wijnhoven, W. N. M. Dinjens and M. Pignatelli, "Ecadherin-Catenin Cell-Cell Adhesion Complex and Human Cancer," British Journal of Surgery, Vol. 87, No. 8, 2000, pp. 992-1005. http://dx.doi.org/10.1046/j.1365-2168.2000.01513.x

[15] H. Brikedal-hansen, W. G. I. Moore, M. K. Bodden, et al., "Matrix Metalloproteinases: A Review," Critical Reviews in Oral Biology \& Medicine, Vol. 4, No. 2, 1993, pp. 197-250.

[16] M. Yoshimoto, F. Itoh, H. Yamamoto, et al., "Expression of MMP-7 (Pump-1) mRNA in Human Colorectal Cancers," International Journal of Cancer, Vol. 54, No. 4, 1993, pp. 614-618. http://dx.doi.org/10.1002/ijc.2910540415

[17] A. Senota, F. Itoh, H. Yamamoto, et al., "Relation of Matrilysin Messenger RNA Expression with Invasive Activity in Human Gastric Cancer," Clinical and Experimental Metastasis, Vol. 16, No. 4, 1998, pp. 313-321. http://dx.doi.org/10.1023/A:1006509312674

[18] A. J. Docherty, J. O'Conell, T. Crabbe, et al., "The Ma- trix Metalloproteinases and Their Natural Inhibitors: Prospects for Treating Degenerative Tissue Diseases," Trends in Biotechnology, Vol. 10, 1992, pp. 200-207. http://dx.doi.org/10.1016/0167-7799(92)90214-G

[19] L. Matrisian, "Metalloproteinases and Their Inhibitors in Matrix Remodeling," Trends in Genetics, Vol. 6, 1990, pp. 121-125. http://dx.doi.org/10.1016/0168-9525(90)90126-Q

[20] L. A. Liotta, "Tumor Invasion and Metastases-Role of the Extracellular Matrix: Rhoads Memorial Award Lecture," Cancer Research, Vol. 46, No. 1, 1986, pp. 1-7.

[21] L. A. Liotta and E. C. Kohn, "The Microenvironment of the Tumour-Host Interface," Nature, Vol. 411, No. 6835, 2001, pp. 375-379. http://dx.doi.org/10.1038/35077241

[22] P. M. Comoglio and L. Trusolino, "Invasive Growth: From Development to Metastasis," Journal of Clinical Investigation, Vol. 109, No. 7, 2002, pp. 857-862.

[23] L. M. Coussens and Z. Werb, "Matrix Metalloproteinases and the Development of Cancer," Chemistry \& Biology, Vol. 3, No. 11, 1996, pp. 895-904. http://dx.doi.org/10.1016/S1074-5521(96)90178-7

[24] L. E. Littlepage, M. Egeblad and Z. Werb, "Coevolution of Cancer and Stromal Cellular Responses," Cancer Cell, Vol. 7, No. 6, 2005, pp. 499-500. http://dx.doi.org/10.1016/j.ccr.2005.05.019

[25] R. Lichtinghagen, T. Helmbrecht, B. Arndt, et al., "Expression Pattern of Matrix Metalloproteinases in Human Liver," European Journal of Clinical Chemistry and Clinical Biochemistry, Vol. 33, 1995, pp. 65-71.

[26] A. H. Baker, D. R. Edwards and G. Murphy, "Metalloproteinase Inhibitors: Biological Actions and Therapeutic Opportunities," Journal of Cell Science, Vol. 115, No. 19, 2002, pp. 3719-3727. http://dx.doi.org/10.1242/jcs.00063

[27] T. E. Curry Jr. and K. G. Osteen, "The Matrix Metalloproteinase System: Changes, Regulation, and Impact through the Ovarian and Uterine Reproductive Cycle," Endocrine Review, Vol. 24, No. 4, 2003, pp. 428-465. http://dx.doi.org/10.1210/er.2002-0005

[28] C. M. Dollery, J. R. McEwan and A. M. Henney, "Matrix Metalloproteinases and Cardiovascular Disease," Circulation Research, Vol. 77, No. 5, 1995, pp. 863-868. http://dx.doi.org/10.1161/01.RES.77.5.863

[29] S. F. Yan, M. K. Chen, Y. S. Hsieh, et al., "Antimetastatic of Terminalia catappa L on Oral Cancer via Down Regulation of Metastasis-Associated Proteses," Food Chemical Toxicology, Vol. 48, No. 4, 2012, pp. 1052-1058.

[30] C. B. Yeh, M. J. Hsieh, Y. H. Hseih, et al., "Antimetastatic Effects of Norcantharidin on Hepatocellular Carcinoma by Transcriptional Inhibition of MMP-9 through Modulation of NF-kB Activity," Plos ONE, Vol. 45, 2012, pp. 234-236.

[31] C. B. Yeh, M. J. Hsieh, Y. S. Hsieh, M. H. Chien, P. Y. Lin, H. L. Chiou, et al., "Terminalia Catappa Exerts Antimetastatic Effects on Hepatocellular Carcinoma through Transcriptional Inhibition of Matrix Metalloproteinase-9 by Modulating NF- $\mathrm{B}$ and AP-1 Activity," EvidenceBased Complementary and Alternative Medicine, Vol. 59, 2012, pp. 52-92. 
[32] R. Parkash and P. John, "Macrophages: Central Regulator of Hepatic Fibrogenesis and Fibrosis Resolution," Journal of Hepatology, Vol. 56, No. 6, 2012, pp. 1417-1419. http://dx.doi.org/10.1016/j.jhep.2011.10.026

[33] B. Marina and D. Schuppan, "Progression of Liver Fibrosis in Post-Transplant Hepatitis C: Mechanism, Assessment and Treatment," Journal of Hepatology, Vol. 58, No. 5, 2013, pp. 1028-1041. http://dx.doi.org/10.1016/j.jhep.2012.12.014

[34] L. Yan, N. Borregaard, L. Kjeldsen and M. A. Moses, "The High Molecular Weight Urinary Matrix Metalloproteinase (MMP) Activity Is a Complex of Gelatinase B/ MMP-9 and Neutrophil Gelatinase-Associated Lipocalin (NGAL). Modulation of MMP-9 Activity by NGAL," Journal of Biological Chemistry, Vol. 276, No. 40, 2001, pp. 37258-37265.

http://dx.doi.org/10.1074/jbc.M106089200

[35] R. Roy, G. Louis, K. R. Loughlin, D. Wiederschain, S. M. Kilroy, C. C. Lamb, et al., "Tumor-Specific Urinary Matrix Metalloproteinase Fingerprinting: Identification of High Molecular Weight Urinary Matrix Metalloproteinase Species," Clinical Cancer Research, Vol. 14, No. 20, 2008, pp. 6610-6617.

http://dx.doi.org/10.1158/1078-0432.CCR-08-1136

[36] C. A. Fernandez, L. Yan, G. Louis, J. Yang, J. L. Kutok and M. A. Moses, "The Matrix Metalloproteinase-9/Neutrophil Gelatinase-Associated Lipocalin Complex Plays a Role in Breast Tumor Growth and Is Present in the Urine of Breast Cancer Patients," Clinical Caner Research, Vol. 11, 2005, pp. 5390-5395.

http://dx.doi.org/10.1158/1078-0432.CCR-04-2391

[37] M. E. Azab and E. A. El Zayat, "Evaluation of Purified Antigens in Haemagglutination Test (IHA) for Determination of Cross Reactivates in Diagnosis of Fascioliasis and Schistosomiasis," Journal of the Egyptian Society of Parasitology, Vol. 26, No. 3, 1996, pp. 677-685.

[38] A. Radice, L. Bianchi and R. A. Sinico, "Anti-Neutrophil Cytoplasmic Autoantibodies: Methodological Aspects and Clinical Significance in Systemic Vasculitis," Autoimmunity Reviews, Vol. 12, No. 4, 2013, pp. 487-495. http://dx.doi.org/10.1016/j.autrev.2012.08.008

[39] B. Bain, S. Lewis and I. Bates, "Basic Haematological Techniques," In: S. Lewis, B. Bain and I. Bates, Eds., Practical Haematology, Churchill Livingstone, Philadelphia, 2006, pp. 25-58.

[40] G. Walters, L. P. Kuijperst, J. Kaccaki and A. H. Schuurs, "Enzymes Linked Immunosorbent Assay for Hepatitis B Surface Antigen," The Journal of Infectious Disease, Vol. 136, Suppl. 2, 1997, pp. S311-S317. http://dx.doi.org/10.1093/infdis/136.Supplement 2.S311

[41] C. A. Burtis, E. R. Ashwood and D. E. Bruns, "Tietz Textbook of Clinical Chemistry and Molecular Diagnostics," 4th Edition, Elsevier Saunders Company, St Louis, 2006.

[42] T. Makimo and K. Takahara, "Determination of Copper and Zinc in Infants by Atomic Absorption with Discrete Nebulization," Clinical Chemistry, Vol. 27, No. 8, 1981, pp. 1445-1447.

[43] C. Jumper, E. Cobos and C. Lox, "Determination of the
Serum Matrix Metalloproteinase-9 (MMP-9) and Tissue Inhibitor of Matrix Metalloproteinase-1 (TIMP-1) in Patients with Either Advanced Small-Cell Lung Cancer or Non-Small-Cell Lung Cancer Prior to Treatment," Respiratory Medicine, Vol. 98, No. 2, 2004, pp. 173-177. http://dx.doi.org/10.1016/j.rmed.2003.08.014

[44] I. Toshihiko, F. Takehiko and S. Makoto, "Elevated Levels of Circulating Plasma Matrix Metalloproteinase 9 in Non-Small Cell Lung Cancer Patients," Clinical Cancer Research, Vol. 5, No. 1, 1999, pp. 149-153.

[45] K. R. Pedersen, H. B. Ravn, V. E. Hjortdal, R. Narregaard and J. V. Povlsen, "Neutrophil Gelatinase-Associated Lipocalin (NGAL): Validation of Commercially Available ELISA," Scandinavian Journal of Clinical and Laboratory Investigation, Vol. 70, No. 5, 2010, pp. 374382. http://dx.doi.org/10.3109/00365513.2010.486868

[46] B. Gyorgy, M. Elizabeth and H. Stephen, "Hepatocellular Carcinoma in Non-Alcoholic Fatty Liver Disease: An Emerging Menace," Journal of Hepatology, Vol. 56, No. 6, 2012, pp. 1384-1391. http://dx.doi.org/10.1016/j.jhep.2011.10.027

[47] A. Jemal, F. Bray, M. M. Center, et al., "Global Cancer Statistics," CA: A Cancer Journal for Clinicians, Vol. 61, No. 2, 2011, pp. 69-90. http://dx.doi.org/10.3322/caac.20107

[48] H. B. EL-serag, "Hepatocellular Carcinoma," New England Journal of Medicine, Vol. 365, No. 12, 2011, pp. 1118-1127.

[49] F. X. Bosch, J. Ribes, R. Cleries and M. Diaz, "Epidemiology of Hepatocellular Carcinoma," Clinics in Liver Disease, Vol. 9, No. 2, 2005, pp. 191-211. http://dx.doi.org/10.1016/j.cld.2004.12.009

[50] J. P. Michael, "Fibrogenesis II. Metalloproteinases and Their Inhibitors in Liver Fibrosis," American Journal of Physiology-Gastrointestinal and Liver Physiology, Vol. 279, No. 2, 2000, pp. G245-G249.

[51] R. C. Benyon, C. J. Hovell, M. D. A. Gaca, et al., "Progelatinase A Is Produced and Activated by the Hepatic Stellate Cells and Promotes Their Proliferation," Hepatology, Vol. 30, No. 4, 1999, pp. 977-986. http://dx.doi.org/10.1002/hep.510300431

[52] P. J. Winwood, D. Schuppan, J. P. Iredale, et al., "Kupffer Cell-Derived $95 \mathrm{kD}$ a Type IV Collagenase/Gelatinase B: Characterisation and Expression in Cultured Cells," Hepatology, Vol. 22, No. 1, 1995, pp. 304-315.

[53] H. Leyland, J. Gentry, M. J. P. Arthur and R. C. Benyon, "The Plasminogen-Activating System in Hepatic Stellate Cells," Hepatology, Vol. 24, No. 5, 1996, pp. 1172-1178. http://dx.doi.org/10.1002/hep.510240532

[54] N. Theret, K. Lehti, O. Musso and B. Clement, "MMP2 Activation by Collagen I and Concanavalin A in Cultured Human Hepatic Stellate Cells," Hepatology, Vol. 30, No. 2, 1999, pp. 462-468. http://dx.doi.org/10.1002/hep.510300236

[55] L. Ralf, H. Omar, S. Thomas, et al., "Expression of Matrix Metalloproteinase-2 and-9 and Their Inhibitors in Pe- 
ripheral Blood Cells of Patients with Chronic Hepatitis C," Clinical Chemistry, Vol. 46, No. 2, 2000, pp. 183192.

[56] B. Ramón, A. David and D. Brenner, "Liver Fibrosis," The Journal of Clinical Investigation, Vol. 115, No. 2, 2005, pp. 209-218.

[57] S. Zhang, L. Li, J. Y. Lin and H. Lin, "Imbalance between Expression of Matrix Metalloproteinase-9 and Tissue Inhibitor of Metalloproteinase-1 in Invasiveness and Metastasis of Human Gastric Carcinoma," World Journal of Gastroenterology, Vol. 9, No. 5, 2003, pp. 899-904.

[58] G. Zu, S. Maria, L. Wen, et al., "Association of E-Cadherin, Matrix Metalloproteinases, and Tissue Inhibitors of Metalloproteinases with the Progression and Metastasis of Hepatocellular Carcinoma," Modern Pathology, Vol. 19, 2006, pp. 533-540. http://dx.doi.org/10.1038/modpathol.3800554

[59] S. Xu, C. Petersson, M. Carlson and P. Venge, "The Development of an Assay for Human Neutrophil Lipocalin (HNL) to Be Used as a Specific Marker of Neutrophil Activity in Vivo and Vitro," Journal of Immunological Methods, Vol. 171, No. 2, 1994, pp. 245-252. http://dx.doi.org/10.1016/0022-1759(94)90044-2

[60] D. R. Flower, "The Lipocalin Protein Family: A Role in Cell Regulation,” FEBS Letters, Vol. 354, No. 1, 1994, pp. 7-11.

http://dx.doi.org/10.1016/0014-5793(94)01078-1

[61] T. Harald, Z. Volker, T. Susanne, et al., "The Human Neutrophil Lipocalin Supports the Allosteric Activation of Matrix Metalloproteinases," European Journal of Biochemistry, Vol. 268, No. 7, 2001, pp. 1918-1928. http://dx.doi.org/10.1046/j.1432-1327.2001.02066.x
[62] O. S. Kwon, D. Y. Lim, K. A. Kwon, M. G. Chung, D. K. Park, S. S. Kim, et al., "Clinical Usefulness of Plasma Activities of Gelatinase (Matrix Metalloproteinase-2 and 9) in Chronic Liver Disease," Taehan Kan Hakhoe Chi, Vol. 9, No. 3, 2003, pp. 222-230.

[63] K. Suzuki, R. Oyama, E. Hayashi and Y. Arakawa, "Liver Diseases and Essential Trace Elements," Nihon Rinsho, Vol. 54, No. 1, 1996, pp. 85-92.

[64] R. Hatano, M. Ebara, H. Fukuda, M. Yoshikawa, et al., "Accumulation of Copper in the Liver and Hepatic Injury in Chronic Hepatitis C," Journal of Gastroenterology and Hepatology, Vol. 15, No. 7, 2000, pp. 786-791. http://dx.doi.org/10.1046/j.1440-1746.2000.02199.x

[65] R. Hatano, M. Ebara, H. Fukuda, M. Yoshikawa, N. Sugiura, F. Kondo, et al., "Accumulation of Copper in the Liver and Hepatic Injury in Chronic Hepatitis C," Journal of Gastroenterology and Hepatology, Vol. 15, No. 7, 2000, pp. 786-791.

http://dx.doi.org/10.1046/j.1440-1746.2000.02199.x

[66] K. Suzuki, R. Oyama, E. Hayashi and Y. Arakawa, "Liver Diseases and Essential Trace Elements," Nihon Rinsho, Vol. 54, No. 1, 1996, pp. 85-92.

[67] M. N. Rashed, "The Role of Trace Elements on Hepatitis Virus Infections: A Review," Journal of Trace Elements in Medicine and Biology, Vol. 25, No. 3, 2011, pp. 181187. http://dx.doi.org/10.1016/j.jtemb.2011.07.001

[68] C. Pramoolsinsap, N. Promvanit, S. Komindr, et al., "Serum Trace Metals in Chronic Viral Hepatitis and Hepatocellular Carcinoma in Thailand," Journal of Gastroenterology, Vol. 29, No. 5, 1994, pp. 610-615. http://dx.doi.org/10.1007/BF02365444 